\section{The genus Asterina (Asterinaceae) on the members of Myristicaceae in Kerala State, India}

\author{
V.B. Hosagoudar ${ }^{1} \&$ A. Sabeena ${ }^{2}$ \\ 1,2 Tropical Botanic Garden and Research Institute, Palode, \\ Thiruvananthapuram, Kerala 695562, India \\ Email: ${ }^{1}$ vbhosagoudar@rediffmail.com (corresponding author)
}

Members of the family Myristicaceae are distributed from South East Asia to northern Australia and the Pacific Islands and the family represents three genera, namely, Gymnacranthera, Knema and Myristica in Kerala State (Nayar et al. 2006). Of these, Knema attenuata and Myristica malabarica are endemic to Western Ghats and another unidentified species of the genus Myristica were found infected with black mildew fungus. Microscopic examination of these fungi revealed that they belong to the genus Asterina. Hence, a detailed study of these fungal species was carried out to facilitate their identification.

The genus Asterina is represented by about 700 species, characterised by having brown appressoriate mycelium, stellately dehiscing thyriothecium with globose asci and brown uniseptate ascospores.

Date of publication (online): 26 October 2011

Date of publication (print): 26 October 2011

ISSN 0974-7907 (online) | 0974-7893 (print)

Editor: R.K. Verma

Manuscript details:

Ms \# 02642

Received 07 December 2010

Final received 03 June 2011

Finally accepted 04 October 2011

Citation: Hosagoudar, V.B. \& A. Sabeena (2011). The genus Asterina (Asterinaceae) on the members of Myristicaceae in Kerala State, India Journal of Threatened Taxa 3(10): 2143-2146.

Copyright: () V.B. Hosagoudar \& A. Sabeena 2011. Creative Commons Attribution 3.0 Unported License. JoTT allows unrestricted use of this article in any medium for non-profit purposes, reproduction and distribution by providing adequate credit to the authors and the source of publication.

Acknowledgements: We thank the Director, TBGRI, Palode for providing facilities and to Mr. T. Shaju, TBGRI, Palode for identifying the host plants.

\section{OPEN ACCESS | FREE DOWNLOAD}

\section{Asterina knemae attenuatae}

Hosag., Abraham \& T.S. Nayar,

Mycotaxon 67: 487, 1998;

Hosag., Zoos' Print J. 18: 1283, 2003; 21: 2328, 2006. (Fig. 1)

Material examined: 14.ii.1997, on leaves of Knema attenuata (Wallich ex Hook. f. \& Thomson) Warb. (Myristicaceae), TBGRI Campus, Palode, Thiruvananthapuram, Kerala, India, T.S. Nayar HCIO 42462 (type), TBGT 483 (isotype); 10.ii.1997, Peppara Wildlife Sanctuary, Thiruvananthapuram, V.B. Hosagoudar HCIO 4429, TBGT 719.

Colonies epiphyllous, dense, crustose, up to $5 \mathrm{~mm}$ in diameter. Hyphae straight to rarely crooked, branching irregular at acute to wide angles, loosely reticulate, cells $25-30 \times 4-6 \mu \mathrm{m}$. Appressoria alternate, about $1 \%$ opposite, distantly placed, unicellular, broad based to stipitate, mammiform to cylindrical, ovate, entire to 1-4 times sublobate, $7-20 \times 10-12 \mu \mathrm{m}$. Thyriothecia scattered to 1-3 connate, orbicular to slightly ovate, $150-250 \mu \mathrm{m}$ in diameter, margin crenate, irregularly opened at the centre; asci very few, globose to slightly

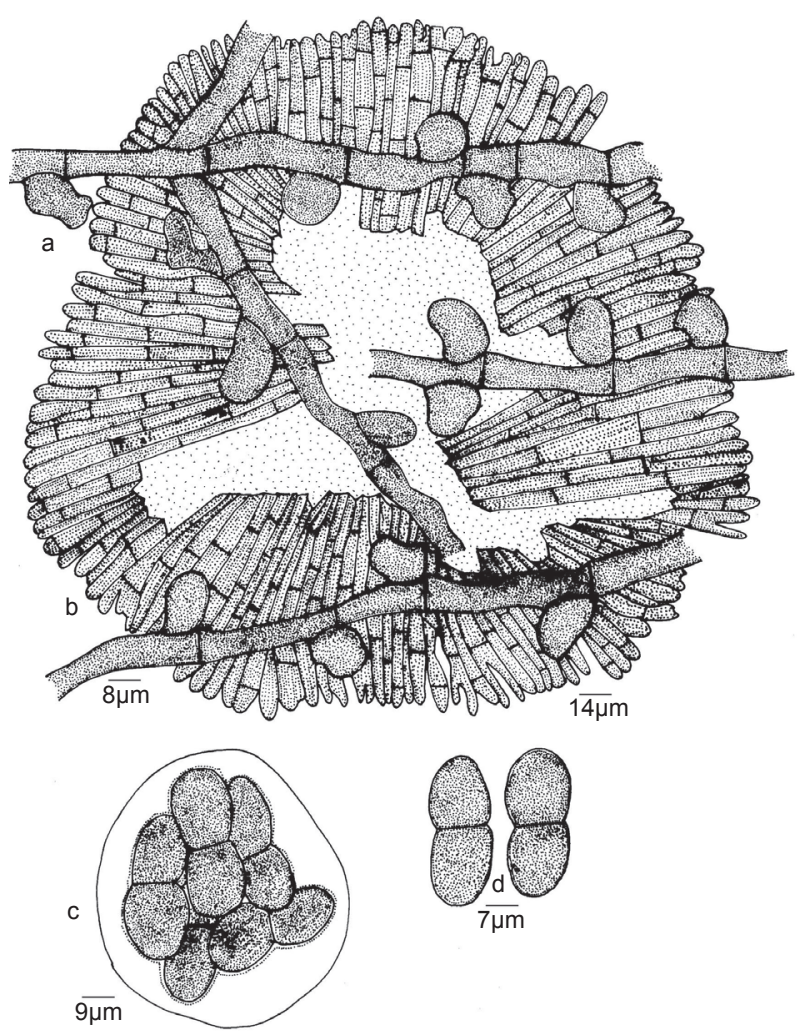

Figure 1. Asterina knemae attenuatae Hosag. a - Appressoriate mycelium; b - Thyriothecium; c - Ascus; d-Ascospores 
ovate, bitunicate, octosporous, $54-58 \times 45-50 \mu \mathrm{m}$; ascospores conglobate, brown, uniseptate, slightly constricted at the septum, $25-27 \times 11-13 \mu \mathrm{m}$, wall glabrous.

Appressoria scattered and about 1\% opposite. Kerala is the type locality for this species (Hosagoudar et al. 1998).

\section{Asterina myristicae sp. nov.}

(Fig. 2)

Material examined: 07.i.2008, on leaves of Myristica sp. (Myristicaceae), Arboretum, TBGRI Campus, Palode, Thiruvananthapuram, Kerala, India, K. Anilkumar TBGT (holotype) (MycoBank 563496). Part of the collection has been deposited in HCIO, New Delhi.

Coloniae hypophyllae, tenues, crustosae, ad $3 \mathrm{~mm}$ diam., confluentes. Hyphae subrectae, flexuosae vel

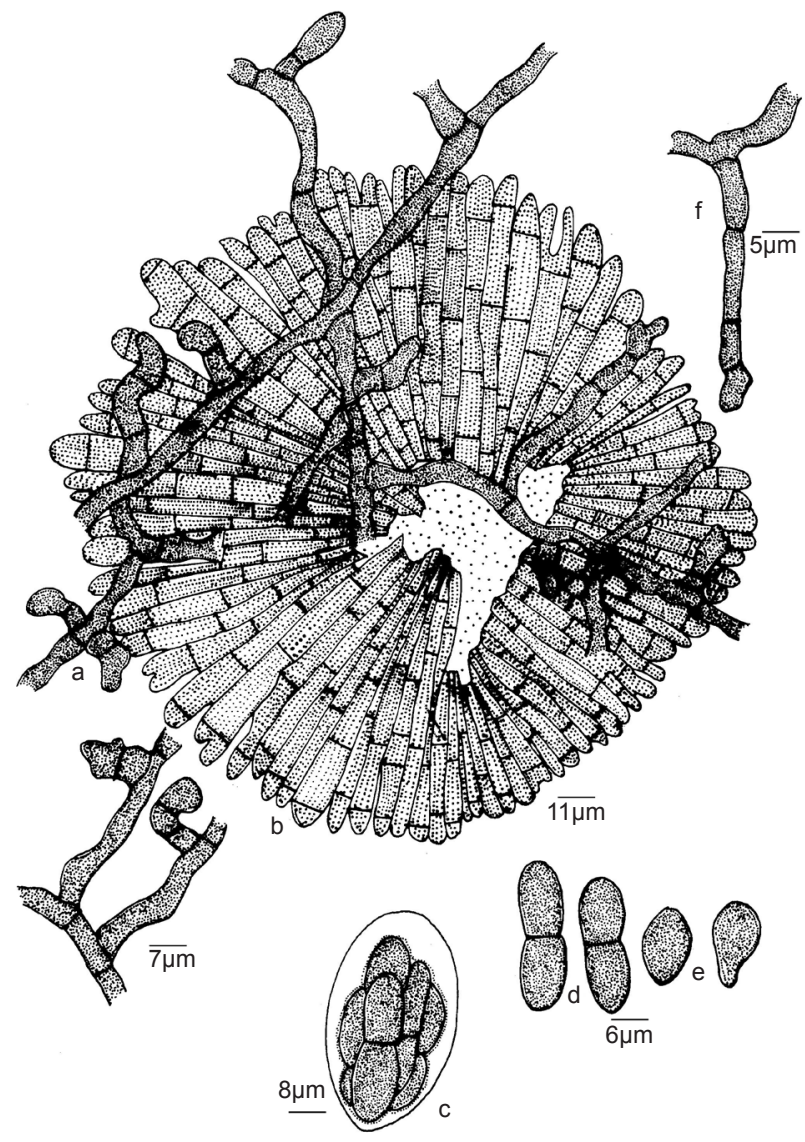

Figure 2. Asterina myristicae sp. nov.

a - Appressoriate mycelium; b - Thyriothecium; c - Ascus; d - Ascospores; e - Pycnothyriospores leniter anfractuae, opposite, alternate vel irregulariter acuteque vel laxe ramosae, laxe vel arte reticulatae, cellulae $12-29 \times 3-5 \mu \mathrm{m}$. Appressoria alternata, opposita, unilateralis, antrorsa, subantrorsa vel retrorsa, 1-3 cellula, recta, curvula, flexuosa vel anfractua, 9-35 $\mu \mathrm{m}$ longa; cellulae basilares unicellularis vel 1-2 septatis, rectae, flexuosae vel anfractuae, 3-27 $\mu \mathrm{m}$ longae; cellulae apicales ovatae, oblongae, rectae vel curvulae, integrae vel sublobatae, 4-11 x 3-8 $\mu \mathrm{m}$. Thyriothecia dispersa vel aggregata, orbicularis vel leniter ovata, ad $160 \mu \mathrm{m}$ diam., margine crenatae, stellatim dehiscentes ad centre; asci numerosi, globosi vel ovati, octospori, 19-40 x 16-25 $\mu \mathrm{m}$; ascosporae brunneae, oblongae, conglobatae, uniseptatae, 16$21 \times 8-10 \mu \mathrm{m}$, parietus glabrus. Pycnothyriosporae brunneae, pyriformes, unicellularis, $12-15 \times 6-10 \mu \mathrm{m}$.

Colonies hypophyllous, thin, crustose, up to $3 \mathrm{~mm}$ in diameter, confluent. Hyphae substraight, flexuous to slightly crooked, branching opposite, alternate to irregular at acute to wide angles, loosely to closely reticulate, cells $12-29 \times 3-5 \mu \mathrm{m}$. Appressoria alternate, opposite, unilateral, antrorse, subantrorse to retrorse, 1-3 celled, straight, curved, flexuous to crooked, 9-35 $\mu \mathrm{m}$ long; stalk cells unicellular to 1-2 septate, straight, flexuous to crooked, 3-27 $\mu \mathrm{m}$ long; head cells ovate, oblong, straight to curved, entire to sublobate, 4-11 x 3-8 $\mu \mathrm{m}$. Thyriothecia scattered to grouped, orbicular to slightly ovate, up to $160 \mu \mathrm{m}$ in diameter, margin crenate, stellately dehisced at the centre; asci many, globose to ovate, octosporous, $19-40 \times 16-25 \mu \mathrm{m}$; ascospores brown, oblong, conglobate, uniseptate, 16-21 x 8-10 $\mu \mathrm{m}$, wall smooth. Pycnothyriospores

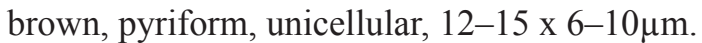

Note: This species stands distinct from all other Asterina species known on the members of Myristicaceae in having 1-3-celled appressoria.

\section{Asterina myristicacearum sp. nov.} (Fig. 3)

Material examined: 30.iv.2008, on leaves of Myristica malabarica Lam. (Myristicaceae), TBGRI Campus, Palode, Thiruvananthapuram, Kerala, India, A. Sabeena \& M.C. Riju TBGT 4979 (holotype) (MycoBank 563497). Part of the collection has been deposited in HCIO, New Delhi.

Coloniae epiphyllae, subdensae, ad $3 \mathrm{~mm}$ diam. 


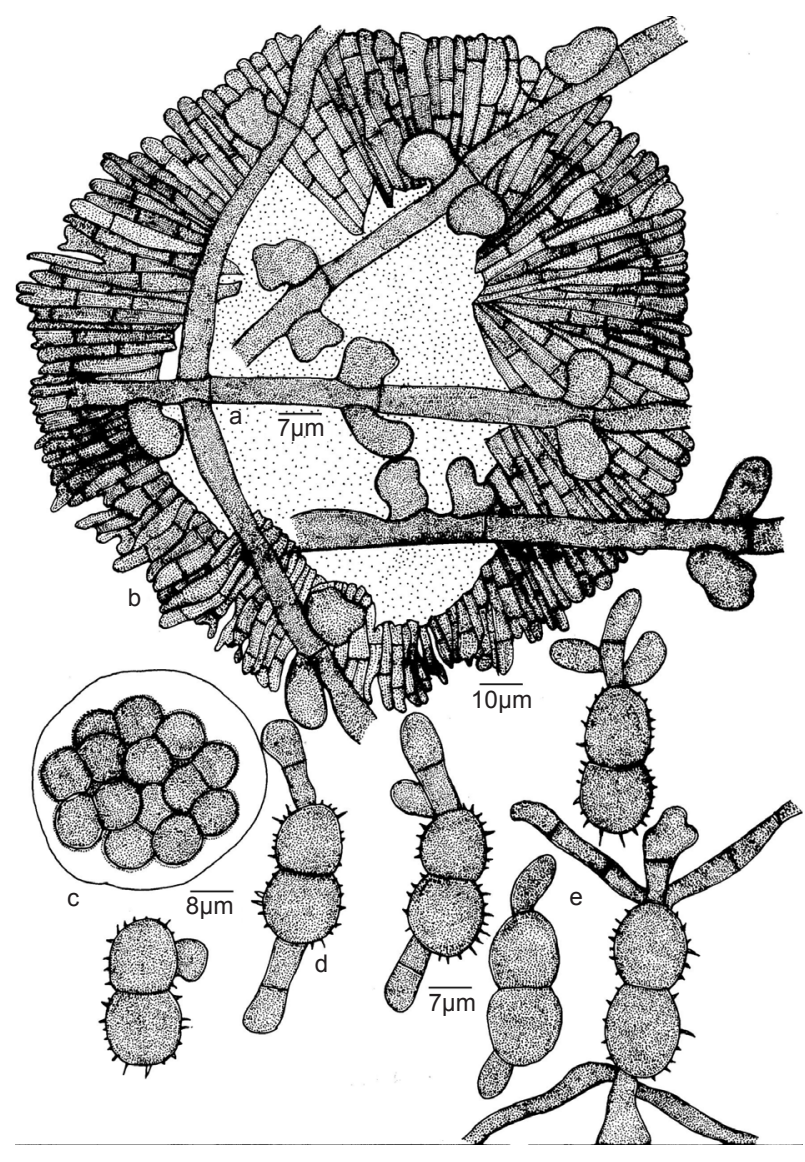

Figure 3. Asterina myristicacearum sp. nov.

a - Appressoriate mycelium; b - Thyriothecium; c - Ascus; d - Germinating ascospores

Hyphae rectae vel subrectae, opposite vel unilateralis acuteque vel laxe ramosae, laxe reticulatae, cellulae $17-47 \times 2-5 \mu \mathrm{m}$. Appressoria saepe dense posita, alternata, opposita vel subopposita, unicellularis, saepe crassa posita, ovata, globosa, integra, angularis vel sublobata, $7-15 \times 7-10 \mu \mathrm{m}$. Thyriothecia dispersa vel connata, ovata, ad $170 \mu \mathrm{m}$ diam., margine crenatae, stellatim dehiscentes ad centre et portionio ad centralis dissolutus; asci globosi, octospori, 37-50 $\mu \mathrm{m}$ diam.; ascosporae conglobatae, brunneae, uniseptatae, constrictus ad septatae, $25-32 \times 12-17 \mu \mathrm{m}$, parietus echinulatus.

Colonies epiphyllous, subdense, up to $3 \mathrm{~mm}$ in diameter. Hyphae straight to substraight, branching opposite to unilateral at acute to wide angles, loosely reticulate, cells $17-47 \times 2-5 \mu \mathrm{m}$. Appressoria often crowded, alternate, opposite to subopposite, unicellular, often broad based, ovate, globose, entire, angular to sublobate, $7-15 \times 7-10 \mu \mathrm{m}$. Thyriothecia scattered to connate, ovate, up to $170 \mu \mathrm{m}$ in diam., margin crenate, stellately dehisced at the centre or the central portion dissolved by exposing asci; asci globose, octosporous, $37-50 \mu \mathrm{m}$ in diam.; ascospores conglobate, brown, uniseptate, constricted at the septum, 25-32 x 12-17 $\mu \mathrm{m}$, wall echinulate.

Note: Crowded appressoria on this host distinguishes from Asterina knemae-attenuatae Hosag. et al. (Hosagoudar \& Abraham 2000). By adding these three taxa, the number of Asterina species known on Myristicaceae in the world is raised to eight and the key is provided here to facilitate their rapid identification.

Key to the Asterina species from Kerala

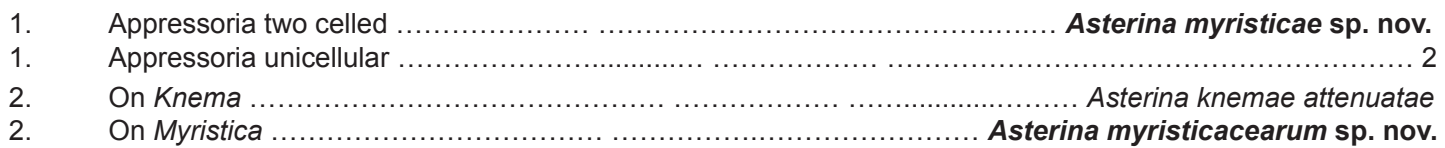

Key to the Asterina species known on Myristicaceae members

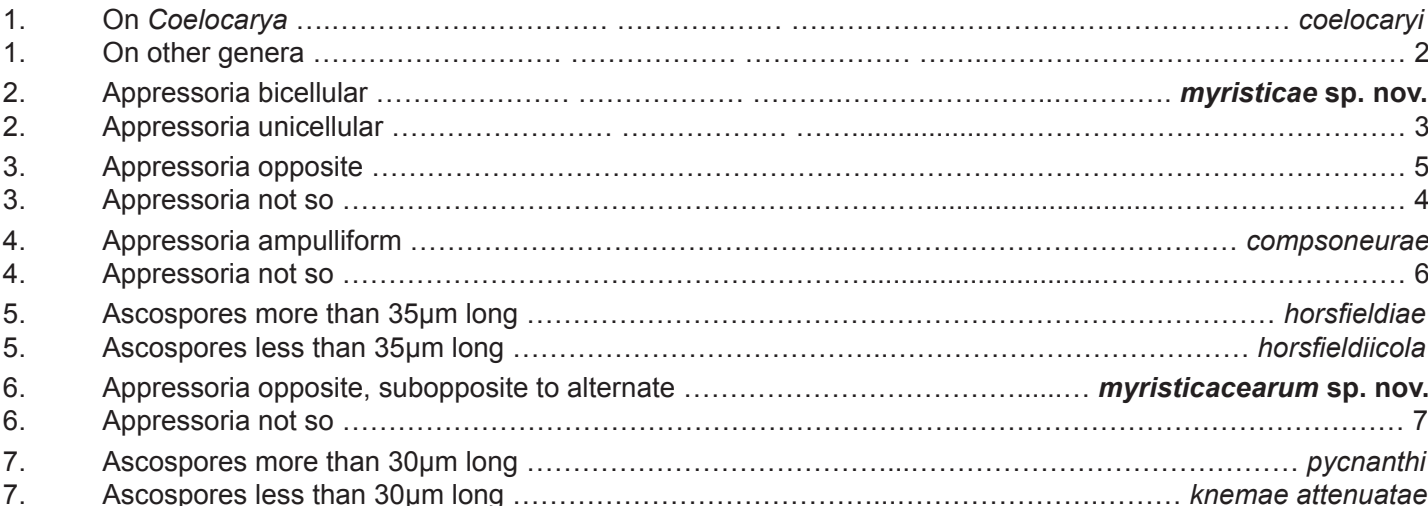




\section{REFERENCES}

Hosagoudar, V.B., T.K. Abraham \& T.S. Nayar (1998). Asterina knemae-attenuatae sp. nov. from India. Mycotaxon 67: 487-488.

Hosagoudar, V.B. \& T.K. Abraham (2000). A list of Asterina Lev. species based on the literature. Journal of Economic and Taxonomic Botany 24: 557-587.

Nayar, T.S., A.R. Beegam, M. Mohanan \& G. Rajkumar (2006). Flowering plants of Kerala. Tropical Botanic Garden and Research Institute, Palode, Thiruvananthapuram, Kerala, 1069pp. 